\title{
IMPACT OF SOCIO-CULTURAL TRANSFORMATION IN THE COMMUNICATIVE DESIGN IN GALICIA
}

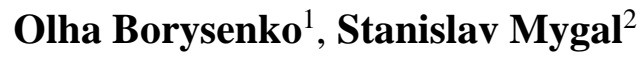

\begin{abstract}
The development of information and communication technologies has determined their spreading in the design of the visual information environment of human activity. This was the main reason for this research - the search for the starting points of the communicative design in Galicia as the phenomenon of artistic-project culture and examining it. The methodological basis of the paper includes interdisciplinary and system approaches in solving the assigned tasks.

The comparative historical analysis and the culturological method has been used to analyze socio-cultural processes in Galicia. This paper analyzes the historical and socio-cultural preconditions for the formation and development of design in Galicia. This paper observed that public organizations, industrial committees, associations, educational and cultural societies have a salience role in improving the design of industrial products. The graphic design of printing products, advertising style, photo, and film productions models the communication characteristics and identity of the graphic design objects.

The result of the probability of design in Galicia was obvious due to the activity of artists, whose graphic design works created harmonious communicative encirclement of human activity.

The complexity of the language of European aesthetics and the sources of national creativity of the Galician masters constituted the paradigmatic basis of communication design. An integral communicative and multifaceted process in the context of sociocultural transformation consolidated the phenomenon of formation and development of design in Galicia..
\end{abstract}

UDC Classification: 655.26:7.012.185](477.83/.86)"18/19" , DOI: https://doi.org/10.12955/pss.v2.202

Keywords: communication design, communication space, Galicia, objects / subjects of graphic design, sign-code.

\section{Introduction}

The research examines the concept of communication design in Galicia of the second half of the 19th century - the first third of the 20th century. The main topics analyzed in the paper are the visualcommunication process in Galicia, periodization of communication design in Galicia, and structure of objects/subjects as communication forms.

The territorial and chronological limits of the research have been conditioned by a number of reasons, among which are the following ones: 1) the unique geopolitical situation of the Galicia in the second half of the 19th - the first third of the 20th century; 2) the region's integration into the socio-economic and cultural life of Austro-Hungarian Empire (1772-1919) i Second Polish Republic (1919-1939); 3) scientific-technical development of the industry in the region of the appointed time, which allow an impulse to the formation of artistic-project activity - the communication design.

The topicality of the research issue is determined by the necessity to study and analyze the emergence of human activity in communicative design. This phenomenon is observed as inseparable from allEuropean processes of design development, and it is an important component of the artistic and design cultural heritage of Ukraine.

\section{Definitions, focus, and methods}

The following fundamental works have become the theoretical basis of the history, culture, and Art of Ukraine and Galicia research. In particular, research of Ukrainian utilitarian art, applied and book graphics, national identity (Kosiv, 2019). The history of the architectural and artistic-industrial education of Galicia, the personalities and artistic processes within the local environment of Galicia, artistic and stylistic directions in the art of Galicia, history, and photography, and culture of Ukrainian cinema of 1897-1939 in Galicia were studied. The basic sources are the works in history, theory, methodology, and practice of communication design (Frascara, 2004).

The primary objective of the research was to find out the factors influencing the communication design formation in the defined period in Galicia. The basics of the communication design sphere are the research tools - the terms "communication space» and "communication design». As Gaines (2006) wrote «The study of space as a semiotic phenomenon suggests that the meaning of space, as a sign, is generally understood in relation to other concerns». The author's periodization of conception of communication design and the typology of objects/subjects of graphic design in Galicia has been developed for this paper.

\footnotetext{
${ }^{1}$ Ukrainian Academy of Printing, Department of Graphic Design and Book Art, Lviv, Ukraine, olga_borysenko@ukr.net

${ }^{2}$ National forest engineering university of Ukraine, Department of Design, Lviv, Ukraine, slava.migal@ukr.net
} 
Such objects/subjects of graphic and art in Galicia, such as posters, cover books, magazines, newspapers, advertising, and photographic, of the period under study, have been identified as design objects/subjects. It helped to find the place of communication design in Galicia in the conditions of socio-cultural transformations of the second half of the 19th century - the first third of the 20th century in the European art and design culture development processes (Borysenko, 2019).

Specific aspects of the development of graphic art, professional architectural design, and artisticindustrial education, the creative work of graphic artists have been examined in the light of fine and folk art, arts-and-crafts, artistic construction, and «technical aesthetics». The conducted analysis of the objects of design graphics, their communication properties has disclosed the basis, displays of formation, and the stages of development of the artistic-project art.

In the functional space of culture, the design occupies the place in the range of material phenomena between the poles of «practical» and «artistic» ones. The design of the objects that are designated first of all for transferring messages belongs to the communication design sphere. The communication design aims to create an object/subject, a visual-information environment, where the creator and consumer, the communicator, and recipient, the addresser and addressee find each other, understand and «speak» a common language (Poleukhin, 2009). The fulfillment of the communication process is possible when there are the following things available: communication space, means of communication, the single system of the codes - signs and their definitions in the context of the visual-communication message transferring.

The analysis of the conceptual basis and the basic definitions of the design, and namely: «communication», «visual communications», «an intention», «communication space», «communication design» has created possibility of disclosing the interdisciplinary character of the communication design. The concept of the communication space reflects the most typical and stable structural properties of the environment in which a person is immersed.

\section{Periodization of communication design in Galicia}

Factors that determined socio-cultural basis and specific signs of communication design in Galicia included the regional ethno-cultural traditions, trade and handicrafts, industrial technologies, architecture, arts, and industrial education, modern processes in European art, and social and national structure of the population. The socio-economic and socio-artistic life of the Austro-Hungarian Empire (1772-1918) and the Second Polish Republic (1918-1939) formation the dualistic orientation of the design development in Galicia. Its development depended on the all-European and Polish artistic processes and from the formation of the national artistic and cultural space. This process in Galicia has been recognized as the first civilization impulse of design culture development. Over the course of centuries, the Ukrainian culture in Galicia was developing in the interaction with Polish, German, Czech and other cultures, the representatives of which lived in the region.

The basis of periodization is some of the important Punkt in the history of Galicia in the second half of the 19th century for communication design conception.

\begin{tabular}{|l|l|}
\hline \multicolumn{2}{|l|}{ Table 1: Important activities of societies, professional artistic-industrial unions } \\
\hline 1848 & $\begin{array}{l}\text { The first Ukrainian newspaper, «Zoria Halyts'ka» (Galician Star) started being published in } \\
\text { Lviv in the single Ukrainian printing house of Stavropigion institute }\end{array}$ \\
\hline 1872 & Chair of drawing and modeling at the Technical academy was founded \\
\hline 1874 & Lviv Industrial museum was founded \\
\hline 1876 & Lviv Art and Industry School was founded \\
\hline 1877 & Organization of the consultation committee of W. Dzieduszycki \\
\hline 1878 & «Polytechnic society» was set up \\
\hline 1884 & Establishing the society of the Ukrainian craftsmen and industrialists «Zoria» (Star) \\
\hline 1888 & Establishing the Hutsul industrial society \\
\hline \multicolumn{2}{|l|}{ Source: Authors } \\
\hline
\end{tabular}

The invention of the first photographs on the territory of Galicia by Gleusner in 1839 led to the mass dissemination of photography already in the second half of the 19th century, which was the precondition of formation of the communication means of photo graphics. The invention of photoplasticons in Galicia 
(1880-s) was the prototype of future films. The cinematographic industry of the first third of the 20th century we consider to be a visual field of cinema graphics, which is a communication design means.

It gives us grounds to believe that already in the second half of the 19th century, we have the prerequisites for the creation of a visual-communication environment, and thus, we can consider this period to be the period of formation and development of the communication design on the territory of Galicia (Borysenko, 2019).

\begin{tabular}{|c|c|c|}
\hline \multirow[t]{7}{*}{$\begin{array}{l}\text { The second } \\
\text { half of the } \\
19^{\text {th }} \\
\text { century }\end{array}$} & \multicolumn{2}{|c|}{$\begin{array}{l}\text { Realization of the problem of the aestheticization of industrial production and its quality } \\
\text { improvement. «Movement for the connection between arts and crafts». } \\
\text { Ideas of G. Ruskin, W. Morris, the consultation committee of W. Dzieduszycki (1877), } \\
\text { theory of G. Zemper }\end{array}$} \\
\hline & $\begin{array}{l}\text { Intensification of activities of } \\
\text { professional societies, trade } \\
\text { unions, public organization, } \\
\text { scientific, educational-cultural } \\
\text { societies. The rise of national } \\
\text { consciousness }\end{array}$ & $\begin{array}{l}\text { Regional commission for the industrial affairs of W. } \\
\text { Dzieduszycki (1878), the society of Ukrainian } \\
\text { craftsmen and industrialists «Zoria» (1884), Hutsul } \\
\text { industrial society (1888), Rus'ky craftsmen and } \\
\text { industrial college (1898) }\end{array}$ \\
\hline & $\begin{array}{l}\text { Formation of professional } \\
\text { architectural design and artistic- } \\
\text { industrial education. City } \\
\text { influence on the development of } \\
\text { design and artistic culture }\end{array}$ & $\begin{array}{l}\text { Chair of drawing and modeling at the architectural } \\
\text { department of the Technical academy (today The } \\
\text { department of design and fundamentals of } \\
\text { architecture of the Architecture Institute of NU } \\
\text { «L'viv Polytechnic») (1872). } \\
\text { Lviv Art and Industrial School (1876) }\end{array}$ \\
\hline & \multicolumn{2}{|c|}{$\begin{array}{l}\text { Converging of scientific-technical and artistic creativity. } \\
\text { Opening of L’viv city industrial museum (1874) }\end{array}$} \\
\hline & $\begin{array}{l}\text { Impulses for communication } \\
\text { design development }\end{array}$ & $\begin{array}{l}\text { Visual messages: books and periodicals, trademarks, } \\
\text { labels, advertisements, posters; new technologies for } \\
\text { circulation of printed production - color } \\
\text { lithography, phototype }\end{array}$ \\
\hline & $\begin{array}{l}\text { International and regional, } \\
\text { artistic-industrial, craft industrial, } \\
\text { and ethnographic exhibitions }\end{array}$ & $\begin{array}{l}\text { Vienna (1859, 1873, 1880, 1889); Paris }(1878, \\
\text { 1889, 1900); L'viv }(1877,1882,1894,1904,1906) ; \\
\text { Kolomyia (1880, 1883, 1885, 1887, 1894, 1912); } \\
\text { Stryi (1909); Stanislaviv }(1879,1884,1900)\end{array}$ \\
\hline & \multicolumn{2}{|c|}{$\begin{array}{l}\text { Popularization of the national idea, transferring of the national factor, visual symbols of } \\
\text { Ukrainian identity to the sphere of industry, and applied graphic art }\end{array}$} \\
\hline \multirow{4}{*}{$\begin{array}{l}\text { The end of } \\
\text { the } 19^{\text {th }}- \\
\text { the first } \\
\text { third of the } \\
20^{\text {th }} \\
\text { century }\end{array}$} & \multicolumn{2}{|c|}{$\begin{array}{l}\text { Scientific-technical progress, technological-innovative craftsmen, and industrial shaping } \\
\text { processes. Integration of art, science, and technology. } \\
\text { The dualistic character of design direction: entering into the all-European and all-Polish } \\
\text { artistic process; formation of national-cultural artistic space }\end{array}$} \\
\hline & $\begin{array}{l}\text { Intensification of the artistic- } \\
\text { project activities in the } \\
\text { communication space }\end{array}$ & $\begin{array}{l}\text { Advertising graphic in periodicals, posters, design } \\
\text { of books and magazines, visual communications of } \\
\text { the city environment, elements of the firm style, } \\
\text { photo-graphics, cinema graphics }\end{array}$ \\
\hline & \multicolumn{2}{|c|}{$\begin{array}{l}\text { Combination of artistic, utilitarian-practical and technical principles in the design objects } \\
\text { of the communication space. The use of traditional technical means and introduction of } \\
\text { the analog information carriers }\end{array}$} \\
\hline & \multicolumn{2}{|c|}{$\begin{array}{l}\text { Development of visual communication, corporate identification, cinema graphics, and } \\
\text { photo-graphics }\end{array}$} \\
\hline
\end{tabular}

A quality of industrial products was improving in Galicia because public and industrial organizations, educational and cultural societies promoted the development of the regional crafts, art and design activities, and national culture.

In particular, the Regional Commission for Industrial Affairs under the guidance of W. Dzieduszycki (1878), the Society of Ukrainian craftsmen and industrialists "Zoria" (1884), Hutsul industrial society (1888), the Rus'ka Handcraft and Industrial School (1898), the Association of Regional manufacturers (1904) and other associations set up under the influence of the European «Arts and Crafts Movement», organized and held the large-scale cultural and artistic events artistic, craft and industrial exhibitions, 
contributed foundation of the first in Ukraine Lviv Art and Industry Museum (1874), Lviv Art and Industry School (1876), the establishment of courses and seminars for small business, etc. (Czasopismo Towarzystwa Technicznego, 1894).

The education program, which combining capability artists, engineers, and architects began of the Drawing and Modelling Department at the Faculty of Architecture of the Technical Academy (1872), today the Department of Design and Architecture Fundamentals of the Architecture Institute of the Lviv Polytechnic National University (Borysenko, 2019).

\section{Visual-communication process in Galicia}

\section{Characteristics and parameters}

The visual-communication process takes place in the technological environment, where the printed information carriers (press, books, advertising production) and analog carriers (photos and cinematography, sign-information objects and buildings) are used (Poleukhin, 2009).

Visual-communication characteristics of these objects/subjects define the communication design parameters in the printed and analog environments.

We consider that the most important of them are the following parameters: space and time; context; composition material; technologies of projects, production, and circulation; color reproduction; semiotic parameters.

An important parameter of communication design is the interaction with the consumer by the communication means of visual identification and communication to address at him/her the visual information/message. This interaction takes place within the communication system, which foresees the availability of the main conditions: the source of information, the sender, technological ways of transmitting the information message in the visual-communication environment, the receiver of this information, the feedback between the receiver and sender.

Artistic and design activity combined with artistic and utilitarian technical principles is the key element, the conceptual core of the communication design. The visual-communicative means of graphic design objects in communication space are corporate identity, advertising printing products (posters, playbills, postcards), elements of exhibition displays, periodicals, and books.

Communication space is what we consider to be a natural socio-economic continuous part of a social system with a set of various existential partial local spaces with internal and external structural and functional interrelated components of procedural-subject forms of expression, visual communication, connection, and interaction (Borysenko \& Mygal, 2019).

For researching the process of formation and development of design in Galicia, there have been distinguished and characterized the factors of influence in the communication space of the researched period. These are the geopolitical, socio-cultural, socio-economical, urban, functional-operational, industrial-technological, sign-information, and artistic aesthetic factors. An important role was played by the peculiarities of the national and ethnic-confessional structure of the region's population, architectural design, and artistic-industrial education; fine art and arts-and-crafts.

\section{Type of design-objects}

Among the objects/subjects of design graphics in the visual-information communication environment of Galicia belong the following: advertising graphics, poster, book and magazine graphics, applied graphics, industrial graphics, photo-graphics, cinema graphics, corporate identification, visual communications, sign-information dimensional-spatial structures.

\begin{tabular}{|c|c|c|}
\hline & \multicolumn{2}{|l|}{ Type } \\
\hline & Printed production & Analog products \\
\hline \multirow{4}{*}{ 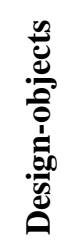 } & Book production (books, brochures) & \multirow{2}{*}{ Photography, photo-graphics } \\
\hline & Periodicals (magazines, newspapers) & \\
\hline & $\begin{array}{l}\text { Accidental-advertising production (postcards, posters, } \\
\text { booklets, goods-accompanying documents) }\end{array}$ & Cinema graphics \\
\hline & \multicolumn{2}{|c|}{$\begin{array}{l}\text { Corporate identification objects (trademark, logotype, elements of corporate style, } \\
\text { pictograms, charts, road signs, signboards, billboards, banners, lightboxes) }\end{array}$} \\
\hline
\end{tabular}


The informational and visual intensity of the graphic design objects/subjects of this the second half of the 19th century - the first third of the 20th century in Galicia is their main stylistic feature. We refer to the design-graphics objects according to their technical and technological characteristics: printed production, analogue production, and corporate identification objects.

\section{The periodicals as a communicative instrument}

An important place was taken by the periodicals, advertising materials in the conception of the communication design of Galicia printed in Ukrainian, Polish and German languages. These tried to extend the circle of consumers and the sales markets for a reader-audience, and in such a way, to improve the communication effectiveness. So the printed word is a significant communication means.

The government reforms of Austria-Hungary giving autonomy to Galicia (1867) contributed to the support of the culture and education. The second half of the 19th century grew the printing and circulation of the Ukrainian-language editions (books, newspapers, magazines) due to abolishing censorship institutions in Galicia.

The Ukrainian periodicals, such as «Dilo», «Buduchnist'», «Galician Rus», «Halychanyn», «Zoria», «Meta», «Rus'ka Rada», «Industrial-Cooperative Magazine», «Stanislavivs'ki Visti» and others, enjoyed great popularity. The Polish press in Galicia was represented by the daily newspapers «Gazeta Lwowska» and «Kurier Lwowski», and the specialized editions: «Przegląd rzemiosła», the monthly «Sylwan», the fortnightly «Robotnik Krawiecki», the fortnightly «Bartnik Postępowy» and other specialized editions. The periodicals in Galicia were also published in Yiddish and German languages, for example, «Dos Jidysche Wort» and «Ostdeutsches Volksblatt» (Figure 1).

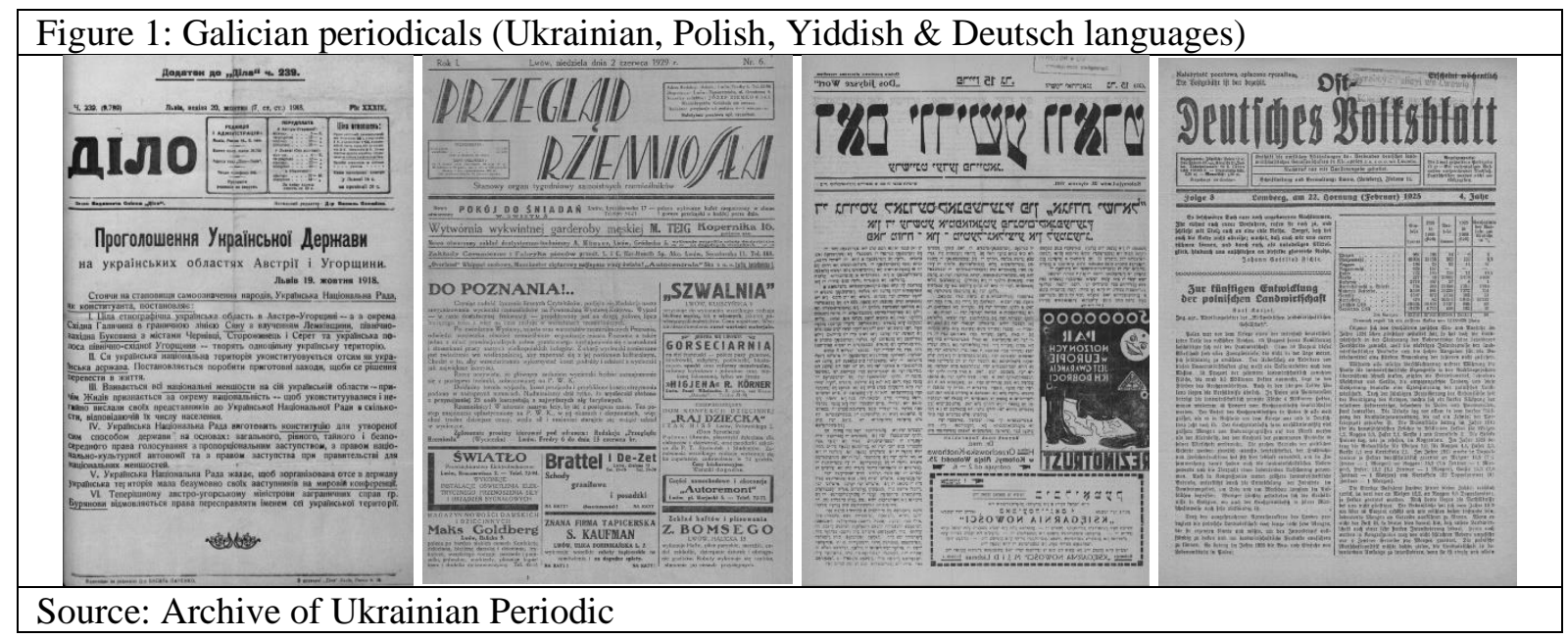

These periodicals contained advertisements as a means of disseminating knowledge and as an image element of the corporate identity of enterprises, factories, and bigger and smaller firms.

The basis of corporate identification was created by the elements of the corporate style of the enterprises of Bachevskyi, Mikoliash, Ruker, Levyns'kyi, and others.

\section{The corporate identity}

In the corporate identity of the enterprises of Ivan Levyns'kyi (1888-1914), there were reflected the Ukrainian ornamental motifs combined with the ornaments of Vienna Secession.

Development of the communication design in Galicia was subordinated to the artistic-project processes of the dualistic direction: all-European and Polish ones.

Scientific-technical progress - the invention of the flatbed printing press, chromolithography, phototype, color photography, linotype, polychromatic letterpress printing, the development of the offset printing technology, and photocomposition have expanded the range of the designers' artistic capabilities in the creation of mass-production visual communication objects/subjects.

Advertising graphics, posters, book and magazine illustrations, applied graphics, industrial graphics, photo graphics, film graphics, corporate identification, visual communications, sign-informational and dimensional-spatial structures tend to draw consumers into their space. 
The visual coherence of the design-graphics objects reflected the font, decorative, ornamental elements of the art and architecture styles of the researched period. An example of such reflection is the Secession graphics, which can be observed in the sign, posters, and covers of Ivan Trush (Figure 2), Maryan Ol'shevs'kyi (Figure 3), etc.

\begin{tabular}{|c|c|}
\hline $\begin{array}{l}\text { Figure 2: Ivan Trush. Design of the magazine } \\
\text { cover «Artystychnyi visnyk» (Artistic bulletin), } \\
1905\end{array}$ & $\begin{array}{l}\text { Figure 3: Maryan Ol'shevs'kyi. Design of } \\
\text { protection mark «Anioł zdrowia» [Angel of } \\
\text { health], } 1913\end{array}$ \\
\hline (Po) & $\mathbb{y}$ \\
\hline $\begin{array}{l}\text { Source: Vasyl Stefanyk National } \\
\text { Scientific Library, Lviv }\end{array}$ & $\begin{array}{l}\text { Source: Borys Voznytsky Lviv National Art } \\
\text { Gallery (author's photo) }\end{array}$ \\
\hline
\end{tabular}

Architectural and artistic trends and European avant-garde movements, such as Secession, art deco, symbolism, futurism, cubism, constructivism, early functionalism, directly influenced the formation of the stylistic priorities, artistic and design parameters of the design objects.

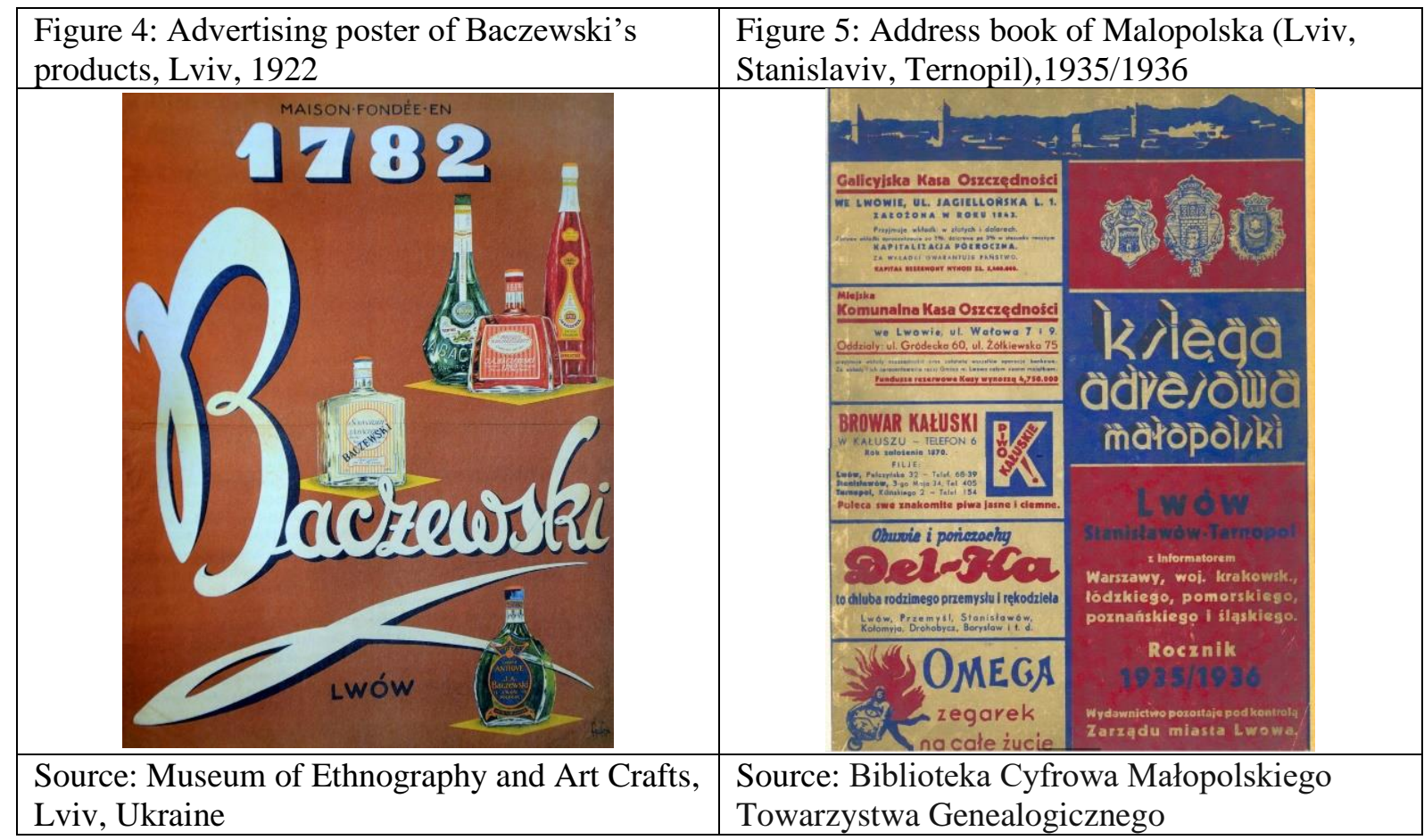

The Secession style characterized by various forms, decorative and plant patterns, and fonts considerably influenced all the spheres of the artistic and design activity in the visual communicative environment in the territory of Galicia at the turn of the 20th century. 


\section{Structure of objects/subjects}

Objects/subjects are semiotic models, which can be considered both at the material and mental levels to reflect the sign-codes in the communication space. The sign in the design objects can be graphic images and formative ones: a packing, signboard construction, exhibition complex.

The basis of the visual-information message is a sign system (font, set) as the main communication means, which are implemented parallelly at two levels: information-visual (text) and visual-graphic (typography) (Figures 4,5). The communication means were used in the printed products, advertising, cinema, and photo production.

The visual-communication tools of objects/subjects of the design-graphic are the font, illustration, photo, corporate identity, advertising, exhibition elements.

The main communication forms are sign-codes and symbols, which create an integral system in combination with font inscriptions. In particular, the trademark and advertising poster became the communication means in Galicia.

Fonts and visuality symbols combined in books and magazines, posters and playbills, objects/subjects of the corporate identity, applied and advertising graphics, sign-information, and dimensional-spatial structures form the semiotic resource of the communication space in Galicia.

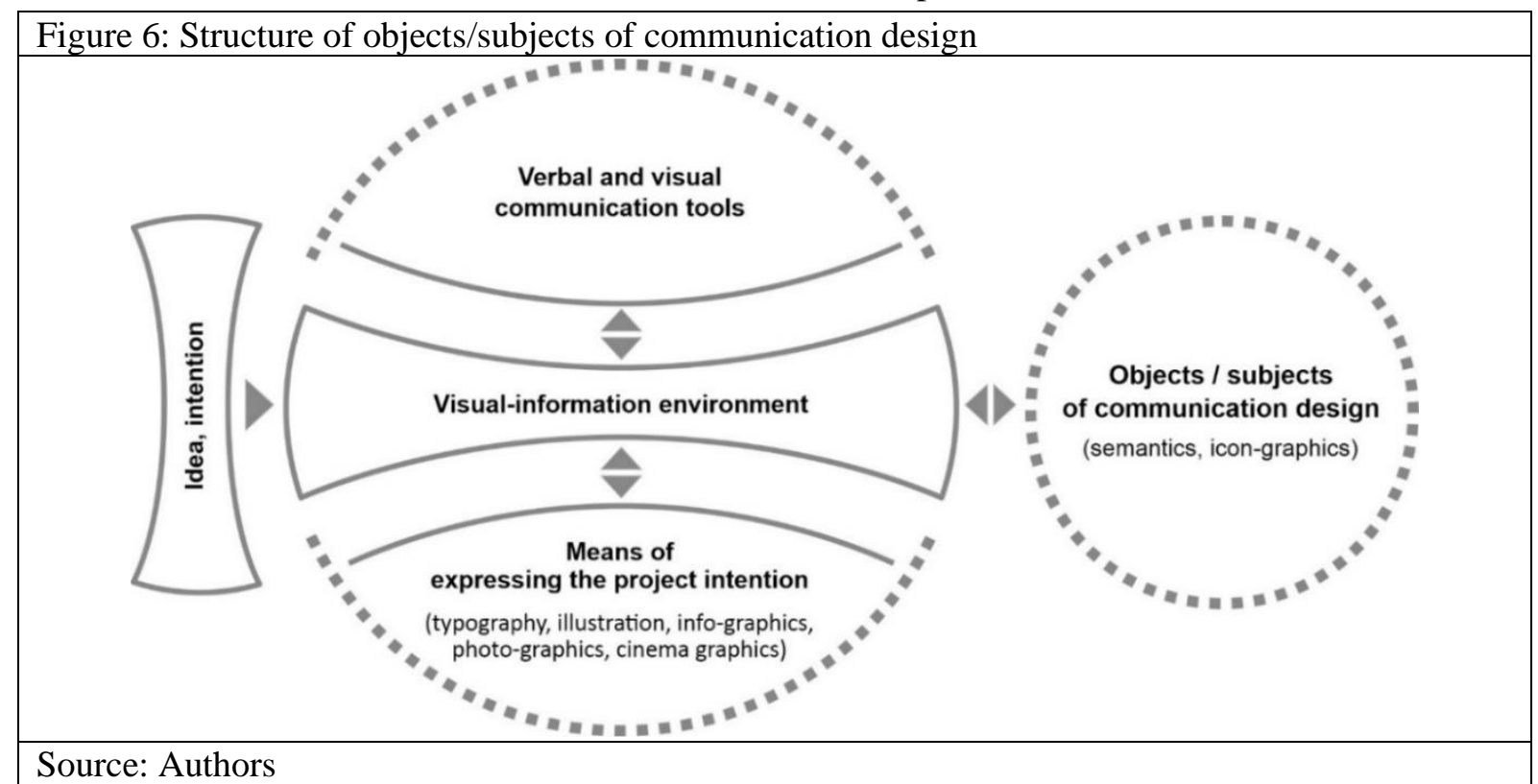

In the researched period visual symbols of the Ukrainian identity, the elements of folk art and arts-andcrafts reflected mainly on pages of periodicals, in advertisements, posters. The Ukrainian trident and other historical symbols are interpreted in the works of such artists as Pavlo Kovzhun, Petro Kholodnyi, Sviatoslav Hordyns'kyi, Robert Lisovs'kyi, Mykola Butovych, Petro Andrusiv, Petro Obal', Vasyl' Diadyniuk, Volodymyr Sichyns'kyi.

Although the Polish government in those times prohibited the use of the national symbol - the trident, artists often placed its interpreted (stylized) variant in the printed products and publisher's marks and trademarks as design (Kosiv, 2019). Due to their communication function, subjects/objects of designgraphics convey in the visual message the national symbolism as an element of Ukrainians' identification. The national cultural space is formed by sign-codes of Ukrainian national identity (red and black color combination, oak leaves, viburnum tassels, sunflowers, embroidery patterns-ornaments, fonts) the communication design.

\section{Discussions and conclusions}

The conducted analysis of the source database has demonstrated that to date, there has been no comprehensive study of the communication design formation and development in Galicia in the second half of the 19th century - the first third of the 20th century; therefore, this problem requires multi-aspect analysis and holistic elaboration as a part of the structure of the visual-information environment. 
For researching the process of formation and development of design in Galicia there have been distinguished and characterized the factors of influence in the communication space of the researched period. These are the geopolitical, socio-cultural, socio-economical, urban, functional-operational, industrial-technological, sign-information, and artistic aesthetic factors. An important role was played by the peculiarities of the national and ethnic-confessional structure of the region's population, architectural design and artistic-industrial education, fine art, and arts-and-crafts.

Books and magazines, illustrations, advertising, and posters in Galicia of the second half of the 19th century - the first third of the 20th century have been examined as a dialogue between the designer and the society, and objects/subjects of communication design for the first time.

During this period, Galicia's rising was influenced by European technologically innovative processes and national artistic form-building.

The artists' creative work caught the artistic and design toolset and showed graphic artworks as communication design objects. These objects were created by tools of typography, photo graphics, and infographics, which are fundamental in communication design. The communicative function of the graphic design objects establishes new connections between the content and the form, which is contained in their graphic tools. It has been determined that the main communication means are sign-codes and symbols that constitute a single integrated system alongside font inscriptions. Some of the visual symbols and signs were a sign of national identity — trident.

We can assert that a trademark and an advertising poster were the first communication means to analyze the documentary graphic materials.

The peculiarities and regularities of the communication design in Galicia discovered allow asserting that the researched heritage is a valuable achievement of Ukrainian culture, which makes evident the social development and progress in the panoramic context of the all-European artistic and design culture.

\section{References}

Archive of Ukrainian Periodics (2021). Retrieved March 01, 2021, from https://libraria.ua/.

Address book of Malopolska (Lviv, Stanislaviv, Ternopil) with city information on Warsaw, as well as Krakow, Pomorskie, Poznan and Silesian provinces (1935/1936). Biblioteka Cyfrowa Małopolskiego Towarzystwa Genealogicznego. http://www.mtg-malopolska.org.pl/images/skany/ksiega_adresowa_1935_36/ksiega_adresowa_1935_36.djvu.

Borysenko, Olha (2019) Akademische Arbeiten mit «Österreich-Bezug» [Academic work with «Austria reference»], Österreich-Bibliotheken im Ausland. Retrieved March, 25, 2021, from https://www.bmeia.gv.at/oesterreichbibliotheken/auslands-austriaca/.

Borysenko, O. M. (2019) Stanovlennia i rozvytok komunikatyvnoho dyzainu v Galychyni druhoyi polovyny XIX - pershoyi tretyny XX stolit' [Formation and development of communication design in Galicia in the second half of the 19th century the first third of the 20th century] (PhD thesis), Lviv, Lviv Polytechnic National University. Retrieved March, 25, 2021, from http://ena.lp.edu.ua:8080/handle/ntb/45469.

Borysenko, O. \& Mygal, S. (2019), Formation and development of graphic Design in communicative of Galicia, Science, and society - Methods and problems of practical application. Proceedings of the 7th International conference, Accent Graphics Communications \& Publishing, Vancouver, Canada, pp. 6-11, https://doi.org/10.29013/VII-Conf-Canada-7-6-10.

Crilly, N., Good, D., Matravers, D., \& Clarkson, J. (2008). Design as communication: exploring the validity and utility of relating intention to interpretation. Design Studies, 29 (5), 425-457. https://doi.org/10.1016/j.destud.2008.05.002.

Czasopismo Towarzystwa Technicznego (1894), [Journal of the Technical Society], no 13, Krakow. Jagiellonian Digital Library. Retrieved March, 01, 2021, from https://jbc.bj.uj.edu.pl/dlibra/publication/353840/edition/337892/content.

Frascara, J. (2004), Communication design: principles, methods, and practice, Allworth Press, New York, 208 p.

Gaines, E. (2006), Communication and the Semiotics of Space, Journal of Creative Communications, 1 (2), pp. 173-181, https://doi.org/10.1177/097325860600100203

Karolczak, K. (2016), Włodzimierz hr. Dzieduszycki (1825-1899) - mecenas nauki i uczonych [Count Vladimir Dzieduszycki (1825-1899) — a patron of science and scholars], Pauza akademicka, № 333/334, 24-31 mart., pp. 2-5.

Klimashevsky, A. (Ed.) (2020), Keramichnyy kod Ivana Levyns'koho v estetychnomu vymiri ukrayintsya kintsya XIX pochatku XX st. [Ceramic code of Ivan Levynsky in the aesthetic dimension of the Ukrainian of the late XIX - early XX centuries], Lviv, Institute of Ethnology of the National Academy of Sciences of Ukraine, 256 p. Retrieved March, 01, 2021, from http://www.library.lviv.ua/colection/mistechtvo/KOD_LEVYNSKOGO.pdf.

Kosiv, V. (2019), Ukrayins'ka identychnist' u grafichnomu dyzayni [Ukrainian Identity in Graphic Design], Rodovid, Kyiv, $480 \mathrm{p}$.

Mygal, S. \& Borysenko, O. (2019), Design of Galicia: formation, development, national component, The European Journal of Humanities and Social Sciences, Premier Publishing s.r.o., Vienna, pp. 20-23. 
Poleukhin, A. A. (2009). Razvitie kommunikativnogo dizayna [Communication Design Development], Izvestiya Rossiyskogo gosudarstvennogo pedagogicheskogo universiteta im. A.Y. Gercena, 115. Retrieved March, 10, 2021, from https://cyberleninka.ru/article/n/razvitie-kommunikativnogo-dizayna.

Trush I. (Ed.), (1905). «Artystychnyi visnyk» [Artistic bulletin] Vol 1, P.1. [Artist]. Vasyl Stefanyk National Scientific Library. http://aleph.lsl.lviv.ua:8991/F/?func=direct\&doc_number=000354580\&local_base=LSL01.

Zbiór ustaw i rozporządzeń administracyjnych w Królestwie Galicyi i Lodomeryi z Wielkiem Księstwem Krakowskiem obowiązujących z wyciągiem orzeczeń c. k. Trybunału administracyjnego (1884), podręcznik dla organów c. k. Władz rządowych i Władz autonomicznych, т. 2, wyd. 3. 